\title{
ANALISIS GAYA KEPEMIMPINAN PONDOK PESANTREN AL-HUDA BONGGAH DESA PLOSO KECAMATAN NGANJUK
}

\author{
Muhamad Juhan Junaidi \\ Madrasah Tsanawiyah Al Huda Bogo Nganjuk \\ Johanjunaid 108@gmail.com \\ Suko Susilo \\ Institut Agama Islam Tribakti Kediri \\ sukosusilo.ag1no@gmail.com
}

\begin{abstract}
Abstrak
Kyai merupakan pemimpin di pondok pesantren yang mempunyai peran sangat penting dan sangat strategis dalam mewujudkan suatu tujuan, mengingat posisinya yang secara struktural sebagai pimpinan legal memiliki kekuasaan penuh pada lembaga yang dipimpinnya. Kyai merupakan pimpinan tertinggi dalam lembaga pendidikan di pondok pesantren. Gaya kepemimpinan Kyai sangatlah mempengaruhi terwujudnya madrasah yang memenghasilkan manusia - manusia yang bertakwa, berbudi pekerti luhur, dan manusia yang multi tailen. Atas dasar itu, penelitian ini difokuskan pada gaya Kepemimpinan Pondok Pesantren AlHuda Bonggah Ploso Nganjuk. Penelitian ini bertujuan (1) Mendeskripsikan Kecenderungan orientasi Prilaku Kepemimpinan Pondok Pesantren Al-Huda Bonggah Desa Ploso Kecamatan Nganjuk Kabupaten Nganjuk. (2) Mendeskripsikan Gaya Kepemimpinan Pondok Pesantren Al-Huda Bonggah Desa Ploso Kecamatan Nganjuk Kabupaten Nganjuk. Hasil penelitian menunjukkan bahwa : (1) Prilaku Kepemimpinan Pondok Pesantren Al-Huda Bonggah kecenderungan yang tinggi orientasinya pada pembinaan kekompakan kelompok sekaligus pada pencapaian tujuan (2) Gaya kepemimpinan yang diterapkan oleh Pimpinan Pondok Pesantren Al-Huda adalah Demokrasi.
\end{abstract}

Kata Kunci : Gaya Kepemimpinan, Pondok Pesantren

\section{Pendahuluan}

Pondok pesantren bagi masyarakat masih sebagai lembaga yang memainkan peran penting dalam membentuk manusia berbudi pakerti yang luhur. Pondok pesantren diasumsikan sebagai bengkel bagi manusia yang dalam kehidupan sehari-hari telah dirasa mempunyai berperilaku yang menyimpang. Banyak orang tua memondokkan anaknya dengan alasan supaya anak tersebut sembuh dari kenakalan. Tetapi tidak sedikit orang tua yang memondokkan anaknya demi sebuah cita-cita yang luhur, supaya anak tersebut kelak menjadi anggota masyarakat yang mampu berpijak pada ajaran agama, menjadi warga yang mampu memimpin anggota masyarakat lain supaya tetap berdiri di atas pondasi agama, serta menerapkan ajaran agama dalam kehidupan sehari-harinya.
Pondok pesantren salafi sendiri rupanya telah menyadari akan perkembangan zaman. Perubahan juga telah dilakukan oleh Pengasuh untuk semakin meningkatkan mutu pendidikan lembaga mereka. Pondok pesantren salafi di samping tetap memegang tradisi salaf, pengasuh kemudian mencoba mengadakan perluasan wilayah dengan mendirikan atau mengikuti kurikulum dari pemerintah.

Pondok Pesantren Al Huda Bonggah Ploso Nganjuk pada awalnya juga termasuk pondok salafi. Namun pada perkembanganya sekarang telah mengikuti Gaya pondok khalaf. Pondok pesantren salafi maupun khalaf keduanya meskipun telah memiliki jalur pendidikan yang mengikuti kurikulum nasional, namun masih saja mempertahankan kurikulum pondok (sistem pembelajaran salafi). Di Pondok Pesantren Al Huda Bonggah Ploso 
Nganjuk tetap memegang sistem salafi tersebut. Pondok Pesantren Al Huda Bonggah Ploso Nganjuk telah berhasil mengembangkan diri untuk tidak sebatas fokus pada permasalahan keilmuwan agama semata (system pembelajaran khalaf).

Melihat keadaan tersebut, tentunya perhatian dari pengasuh, pengurus, dan masyarakat internal dari Pondok Pesantren Al Huda Bonggah Ploso Nganjuk disibukkan bukan permasalahan pendidikan agama semata, mereka terlibat aktif dalam bidang yang lebih luas. Fakta yang ada bahwa keilmuwan keagamaan pada pondok pesantren tersebut tidak mengendur dan tetap diakui oleh masyarakat. Pondok Pesantren Al Huda Bonggah Ploso Nganjuk membuktikan bahwa meskipun telah berhasil mengikuti perkembangan zaman, tetapi semangat salafi sebagai identitas sebuah pondok pesantren tetap tidak berubah.

Kelemahan sebagian pondok pesantren salafi menurut Mujamil Qomar disebabkan karena "permasalahan manajemen yang kurang tertata rapi dan prinsip serba mono". ${ }^{1}$ Harus disadari bahwa pondok pesantren memang kebanyakan lemah dalam bidang manajemen, serta pondok pesantren tersebut bukan sebuah lembaga milik umum. Artinya ketika ingin mengadakan pembaharuan dalam pondok pesantren, maka sasaran pertama yang harus dibidik adalah pengasuh sebuah pondok pesantren. Jika pandangan pengasuh berubah, secara otomatis akan berdampak kepada sistem yang dijalankan di pondok tersebut.

Keberhasilan merumuskan dan memformat ulang orientasi pondok tanpa merubah identitas salafi ini tidak lepas dari kepemimpinan yang dilakukan oleh pengasuh dan pengurus pondok pesantren guna menjawab tantangan zaman. "Ketika Gaya kepemimpinan pada masyarakat internal menemukan tempatnya, segala kendala yang ada dalam mewujudkan citacita yang telah disepakati oleh pengasuh

1 Mujamil Qomar (2008), Manajemen Pendidikan Islam, Erlangga, hlm. 60. dan pengurus akan menjadi terpecahkan dan mencair dengan sendirinya". Kepemimpinan diperlukan tidak hanya pada pondok pesantren belaka. Kepemimpinan diperlukan dalam lembaga atau organisasi lain supaya tidak terjadi salah paham dan meminimalisir konflik.

Identitas pondok pesantren tergantung Gaya kepemimpinan seorang kyai yang diterapkan di sebuah pondok pesantren dalam merespon perubahan tersebut. Secara umum, dari segi kepemimpinan, pesantren masih terpola secara sentralistik dan hierarkis, terpusat pada seorang kiai. Kiai sebagai salah satu unsur dominan dalam kehidupan sebuah pesantren. Ia mengatur irama pekembangan dan keberlangsungan kehidupan suatu pesantren dengan keahlian, kedalaman ilmu, karisma, dan keterampilannya. Tidak jarang sebuah pesantren tidak memiliki manajemen pendidikan yang rapi, sebab segala sesuatu terletak pada kebijaksanaan dan keputusan kyai.

Seorang kyai dalam budaya pesantren memiliki berbagai macam peran, termasuk sebagai ulama, pendidik dan pengasuh, penghubung masyarakat, pemimpin, dan pengelola pesantren. Peran yang begitu kompleks tersebut menuntut kyai untuk bisa memosisikan diri dalam berbagai situasi yang dijalani. Dengan demikian, dibutuhkan sosok kyai yang mempunyai kemampuan, dedikasi, dan komitmen yang tinggi untuk bisa menjalankan peranperan tersebut.

Pondok Pesantren Al Huda Bonggah Ploso Nganjuk dari awal berdirinya sampai sekarang baru mengalami dua kali pergantian kepemimpinan, namun dari tahun ke tahun terus mengalami perkembangan, baik dari sisi fisik maupun perkembangan mutu pondok pesantren. Hal ini disebabkan karena dalam kepemimpinan baik pengasuh dan pengurus pondok merasa saling melengkapi satu sama lainnya untuk mencapai tujuan yang dicita-citakan. Pengasuh dan pengurus sudah mengerti akan wilayah dan tanggung jawab mereka 
sendiri, sehingga tumpang tindih wewenang tidak terjadi.

Dari sini tampak bahwa peran kyai memainkan peran sentral dalam dinamika kehidupan pesantren itu sendiri. Pola kepemimpinan seperti itu berbeda dengan pola kepemimpinan yang diterapkan pada lembaga pendidikan di luar pesantren (seperti lembaga pendidikan formal) yang cenderung menerapkan pembagian kewenangan secara struktural dalam menjalankan proses belajar mengajarnya.

Dalam pesantren, pola kepemimpinan biasanya berwatak kharismatis. Hal ini karena, biasanya pesantren didirikan oleh seseorang yang bercita-cita tinggi dan mampu mewujudkan cita-citanya itu. Proses pendirian pesantren secara demikian ini menampilkan seorang pemimpin yang tertempa oleh pengalaman, memiliki keunggulan kepribadian yang dapat mengalahkan pribadi-pribadi lain di sekitarnya.

Kekuatan pribadi seperti itu menimbulkan corak kepemimpinan yang sangat pribadi sifatnya, yang berlandaskan penerimaan masyarakat luar dan warga pesantrennya secara mutlak. Sifat mutlak dan pribadi dari kepemimpinan seperti inilah yang dinamai kharisma. Pada tahaptahap pertama berkembangnya sebuah pesantren memang diperlukan kepemimpinan dengan sifat-sifat demikian itu, namun pada tahap-tahap selanjutnya banyak kerugian yang ditimbulkannya. ${ }^{2}$

Pada perkembangannya di Pondok Pesantren Al Huda Bonggah Ploso Nganjuk tetap diakuinya pola kepemimpinan yang karismatik meski dalam proses penentuan/pemilihanya adalah menggunakan cara demokratis. Sehingga telah memaksa (kepemimpinan) Pondok Pesantren Al Huda Bonggah Ploso Nganjuk memikirkan kembali apa-apa yang selama ini dipegangnya, mulai dari gaya kepemimpinan, komunikasi antar pemimpin, transformasi pola berfikir santri-santrinya, dan sebagainya. Karena tanpa disadari jaringan modernitas telah

2 Abdurrahman Wahid (2007), Menggerakkan Tradisi Esai-Esai Pesantren, Yogyakarta: LKiS, hlm. 179-194. masuk keseluruh bangunan kehidupan manusia sebagai konsekuensi logis dari perkembangan pengetahuan dan gejala dunia.

Pondok Pesantren Al Huda Bonggah Ploso Nganjuk merupakan salah satu pondok pesantren yang mengalami perkembangan yang signifikan di kabupaten Nganjuk, meskipun Kyai bukanlah seorang yang mengeyam pendidikan formal, akan tetapi Kyai sangat peduli akan pendidikan formal, hal tersebut bisa dilihat dari putra-putri Kyai yang di sekolahkan di pendidikan umum sampai tingkat perguruan tinggi.

Disamping itu Kyai mempunyai kepribadian yang sabar, perhatian pada aktifitas santri, mempunyai menejemen kepemimpinan, mempunyai ratusan santri, mempunyai lembaga formal dan non formal, mempunyai fasilitas yang memadai dan memiliki sumber ekonomi pondok pesantren. Meskipun demikian, kepemimpinan kyai di pesantren cenderung rendah perhatiannya pada hasil sekaligus rendah perhatiannya pada kekompakan anggota. Sehingga secara rasional perilaku kepemimpinan ini dinilai kurang efektif. ${ }^{3}$

\section{Kerangka Teori \\ Konsepsi Kepemimpinan dalam Islam}

Kepemimpinan dalam Islam disebut "imamah". Imamah dari kata "imam" yang artinya "pemimpin" atau" ketua"dalam suatu organisasi atau lembaga. ${ }^{4}$ Pemimpin berperilaku untuk membantu organisasi dengan kemampuan maksimal dalam mencapai tujuan. ${ }^{5}$ Pemimpin tidak berdiri sendiri, melainkan mereka memberikan dorongan dan memacu (to prod), berdiri di depan yang memberikan kemudahan untuk kemajuan serta memberikan

3 Zaenal Arifin. (2016). Efektifitas Kepemimpinan Lembaga Pendidikan Islam di Pesantren. Jurnal Pemikiran Keislaman, 27(1), 40 64. https://doi.org/10.33367/tribakti.v27i1.258

${ }^{4}$ Aminuddin dkk (2010), Pendidikan Agama Islam untuk Perguruan Tinggi Umum, Ghalia Indonesia, Bogor, hlm. 209

5 Wahjosumidjo (2010),Kepemimpinan Kepala MadrasahTinjauan Teoritik dan Permasalahannya, PT Raja Grafindo Parsada, Jakarta, hlm. 104 
inspirasi organisasi dalam mencapai tujuan. Kepemimpinan merupakan proses ketika seseorang berupaya memengaruhi sekelompok orang untuk mencapai kesuksesan atau tujuan bersama. ${ }^{6}$

Secara sederhana kepemimpinan diartikan sebagai pelaksanaan otoritas dan pembuatan keputusan, pengertian tersebut menunjukkan bagaimana seorang pemimpin mampu menggunakan kewenangan untuk menggerakkan organisasi melalui keputusan yang dibuat. Sedangkan menurut istilah kepemimpinan adalah proses mempengaruhi aktivitas individu atau group untuk mencapai tujuan-tujuan tertentu dalam situasi yang telah ditetapkan. Dalam mempengaruhi aktifitasnya individu pemimpin menggunakan kekuasaan, kewenangan, pengaruh, sifat dan karakteristik, dan Tujuannya adalah meningkatkan produktivitas dan moral kelompok. ${ }^{7}$

Dalam Islam istilah kepemimpinan sering diidentikkan dengan istilah khilafah dan orangnya di sebut kholifah dan Ulil Amri yang orangnya disebut Amir (pemimpin). ${ }^{8}$

Kepemimpinan merupakan kemampuan dan keterampilan seseorang yang menduduki jabatan sebagai pemimpin suatu kerja untuk mempengaruhi prilaku orang lain terutama bawahanya untuk berfikir dan bertindak sedemikian rupa sehingga melalui prilaku yang positif ia memberikan sumbangsih nyata dalam pencapaian tujuan organisasi. ${ }^{9}$

Hal ini dapat dipahami dari penjelasan sebagai berikut: Kepemimpinan didefinisikan secara luas sebagai proses proses yang memengaruhi interpretasi mengenai peristiwa-peristiwa para pengikut, pilihan dari sasaran-sasaran bagi kelompok atau orang, pengorganisasian dari aktivitas-aktivitas tersebut untuk

6 Arini Tathagati (2016), Orang Kreatif Memimpin Dunia, Progressio Jakarta, hlm. 35

7 Imam Suprayogo, (2011), Revormulasi Visi Pendidikan Islam, Stain Press, cet. I, Malang, hlm. 161

8 Ibid,...hal 162

9 Moch Idochi Anwar (2014), Administrasi Pendidikan Dan Manajemen Biaya Pendidikan, Alfabeta, Bandung, hlm. 77 mencari sasaran, pemeliharaan hubungan, kerjasama dan teamwork, serta perolehan dukungan dan kerjasama dari orang orang yang ada diluar kelompok atau orang.

Secara definisi, kepemimpinan memiliki berbagai perbedaan pada berbagai hal, namun demikian yang pasti ada pada definisi kepemimpinan adalah adanya suatu proses dalam kepemimpinan untuk memberikan pengaruh sosial pada orang lain, sehingga orang lain tersebut menjalankan suatu proses sebagaimana yang diinginkan oleh pemimpin, sebagaimana dinyatakan oleh Muhaimin. ${ }^{10}$

Kepemimpinan sering didefinisikan sebagai proses membuat orang lain terinspirasi untuk bekerja keras dalam menyelenggarakan tugas-tugas penting. ${ }^{11}$ Tetapi pengertian tersebut sering dikaitkan dengan dasar-dasar kepemimpinan yang efektif,yakni cara seorang pemimpin atau manajer menggunakan poweruntuk mempengaruhi perilaku orang lain.

Dapat dianalisis unsur-unsur kepemimpinan sebagai berikut: (a) ada orang-orang yang memimpin, mempengaruhi dan memberikan bimbingan, (b) ada orang yang dipengaruhi atau pengikut seperti anggota organisasi, bawahan maupun kelompok yang mau dikendalikan, (c) adanya kegiatan tertentu dalam menggerakkan bawahan untuk mencapai tujuan bersama, (d) adanya tujuan yang diperjuangkan melalui serangkaian tindakan.

Secara lebih ringkas, dapat dijabarkan bahwa unsur-unsur kepemimpinan dalam sebuah organisasi adalah sebagai berikut : a. orang-orang sebagai motor atau daya penggerak di satu pihak, b. orang-orang sebagai sumber di lain pihak.

Kepemimpinan adalah Usaha yang dilakukan oleh seseorang dengan segenap kemampuan yang dimilikinya untuk : mempengaruhi, mendorong, mengarahkan

10Muhaimin (2010), et.al,Manajemen dan Kepemimpinan Sekolah/Madrasah, Kencana Prenada Media Group, Jakarta, hlm. 29

11 Agus Dwiyanto (2010), Reformasi Birokrasi, kepemimpinan dan Pelayanan Publik,Gava Media,Yogyakarta, hlm. 219 
dan menggerakkan orang-orang yang dipimpin supaya mereka mau bekerja dengan penuh semangat dan kepercayaan dalam mencapai tujuan-tujuan organisasi. ${ }^{12}$

Dari definisi di atas dapat disimpulkan bahwa kepemimpinan adalah kelebihan kesanggupan berupa kualitas kerja dari seorang pemimpin untuk mempengaruhi orang-orang agar mau melakukan kegiatan-kegiatan dan bersama-sama mencapai tujuan yang telah ditetapkan dan dengan didukung oleh semua fasilitas yang ada, sehingga pekerjaan berjalan lancar dan tujuan tercapai secara efektif dan efisien.

\section{Keterampilan Kepemimpinan}

\section{a. Skill in leadership}

Dengan kedudukan kepemimpinan saja tidak dapat menjamin seorang pimpinan dapat mengorganisir unit-unit organisasi maupun anggota keompok secara berhasil. Sukses tidaknya seorang pemimpin sangat ditentukan oleh kemampuannya dalam mengaplikasikan fungsi-fungsi kepemimpinannya kedalam proses kerja sama administrative maupun supervise. Pada hakikatnya fungsi-fungsi kepemimpinan yang harus dijalankan itu meliputi : usaha mempengaruhi, mendorong, menggerakkan, membimbing dan mengarahkan orang lain agar orang tersbut mau menerima pengaruh itu serta secara suka rela / penuh antusias berbuat sesuatu untuk mencapai tujuan-tujuan yang ditetapkan. ${ }^{13}$

Agar tujuan yang akan dirumuskan bersama ini dapat berhasil dengan baik, maka mereka diberi kesempatan untuk mengembangkan ide-ide, prosedur kerja dan bahan pembicaraan lainnya, dengan melalui "workshop", team-team atau dalam kepanitiaan. Usaha-usaha di atas akan mempertinggi kreativitas guru-guru, karena mereka merasa mampu membuat keputusan-keputusan yang berharga, rencana-rencana yang bernilai dan

12 Burhanuddin, 2011, Analisis Administrasi Manajemen dan Kepemimpinan Pendidikan, Bumi Aksara, Malang, hlm. 63.

13 Gery Yukl, Leadershhip in Organization, hlm menganggap pimpinan madrasah seperti seorang bapak yang bijaksana.

\section{b. Skill in human relationship}

Di dalam kehidupan warga dalam madrasah tentu terdapat hubungan kemanusiaan yang tidak sehat, situasi semacam itu akan mempunyai pengaruh yang serius semacam itu akan mempunyai pengaruh yang serius terhadap perkembangan pendidikan dan pengajaran di madrasah. Oleh karena itu, pemimpin yang bijaksana akan segera mengambil langkah-lagkah untuk berusaha menciptakan suasana emosional yang sehat bagi madrasah, sehingga tercipta perasaan kekeluargaan yang akrab dan bahagia yang memberi dorongan bekerja yang penuh gairah.

\section{Gaya Kepemimpinan}

Gaya kepemimpinan merupakan perilaku yang digunakan oleh seseorang pada saat orang tersebut mencoba untuk mempengaruhi perilaku orang lain seperti yang dilihat.

Gaya artinya sikap, gerak, tingkah laku, sikap yang elok, gerak-gerik yang bagus, kekuatan, kesanggupan, untuk berbuat baik. ${ }^{14}$

Gaya kepemimpinan adalah cara yang digunakan pemimpin dalam mempengaruhi pengikutnya. ${ }^{15}$

Dalam hal ini pengertian gaya kepemimpinan bisa bermacam-macam, akan tetapi pada dasarnya masih mempunyai benang merah yang sama: (1) Gaya Kepemimpinan adalah sikap, gerakgerik atau lagak yang dipilih oleh seorang pemimpin dalam menjalankan tugasnya. (2) Gaya Kepemimpinan adalah suatu pola perilaku yang konsisten yang ditunjukkan pemimpin dan diketahui pihak lain ketika pemimpin berusaha mempengaruhi kegiatan-kegiatan orang lain. (3) Gaya Kepemimpinan adalah pola perilaku dan strategi yang disukai dan sering diterapkan oleh seorang pemimpin. Gaya

14 Qonita Alya (2011), Kamus Bahasa Indonesia untuk Pendidikan Dasar, Indah Jaya Adipratama, Bandung, hlm. 226

15 E. Mulyasa (2011), Menjadi Kepala Sekolah Profesional, Remaja Rosdakarya, bandung, hlm.108 
kepemimpinan yang dimaksud adalah teori kepemimpinan dari pendekatan perilaku pemimpin. Dari satu segi pendekatan ini masih difokuskan lagi pada gaya kepemimpinan (leadership style), sebab gaya kepemimpinan bagian dari pendekatan perilaku pemimpin yang memusatkan perhatian pada proses dinamika kepemimpinan dalam usaha mempengaruhi aktivitas individu untuk mencapai suatu tujuan dalam suatu situasi tertentu.

Gaya kepemimpinan adalah polapola perilaku pemimpin yang digunakan untuk mempengaruhi aktuivitas orangorang yang dipimpin untuk mencapai tujuan dalam suatu situasi organisasinya dapat berubah bagaimana pemimpin mengembangkan program organisasinya, menegakkan disiplin yang sejalan dengan tata tertib yang telah dibuat, memperhatikan bawahannya dengan meningkatkan kesejahteraanya serta bagaimana pimpinan berkomunikasi dengan bawahannya.

Gaya kepemimpinan merupakan pola perilaku seorang pemimpin yang khas pada saat mempengaruhi anak buahnya, apa yang dipilih oleh pemimpin untuk dikerjakan, cara seorang pemimpin bertindak dalam proses mempengaruhi para anggota kelompok membentuk gaya kepemimpinannya. ${ }^{16}$ Pemaksaan kehendak oleh atasan mestinya tidak dilakukan.

Namun pemimpin dalam menerapkan gaya kepemimpinan yang tepat merupakan tindakan yang bijaksana kepada bawahan, maka akan terjadi kegagalan dalam pencapaian tujuan organisasi. Selanjutnya gaya kepemimpinan digunakan dalam berinteraksi dengan bawahannya, melalui berinteraksi ini antara atasan dan bawahan masing-masing memilki status yang berbeda. Berinteraksinya dua status yang berbeda terjadi, apabila status pemimpin dapat mengerti keadaan bawahannya. Pada umumnya bawahan merasa dilindungi oleh pimpinan apabila pimpinan dapat

16 E. Mulyasa (2013), Manajemen Berbasis Sekolah, Konsep Strategi dan Implementasinya, Remaja Rosdakarya, bandung, hlm. 108 menyejukkan hati bawahan terhadap tugas dibebankan kepadanya. Cara berinteraksi oleh pimpinan akan mempengaruhi tujuan organisasi. Bawahan umumnya lebih senang menerima atasan yang mengayomi bawahan sehingga perasaa senang akan tugas timbul, yang pada akhirnya meningkatkan kinerja karyawan.

Pemimpin yang bijaksana umumnya lebih memperhatikan kondisi bawahan guna pencapaian tujuan organisasi. Gaya yang akan digunakan mendapat sambutan hangat oleh bawahan sehingga proses mempengaruhi bawahan berjalan dengan baik dan disatu sisi timbul kesadaran untuk bekerja sama dan bekerja produktif. Bermacam-macam cara mempengaruhi bawahan tersebut guna kepentingan pemimpin yaitu tujuan organisasi. Pimpinan dalam pencapaian tujuan yang telah ditetapkan pada tugas dan fungsi, melalui proses komunikasi dengan bawahannya sebagai dimensi dalam kepemimpinan dan teknik-teknik untuk memaksimalkan pengambilan keputusan.

Gaya kepemimpinan adalah suatu cara yang digunakan pemimpin dalam berinteraksi dengan bawahanya. ${ }^{17}$ Pola dasar terhadap gaya kepemimpinan yang lebih mementingkan pelaksanaan tugas oleh para bawahannya, menuntut penyelesaian tugas yang dibebankan padanya sesuai dengan keinginan pimpinan. Pemimpin menuntut setiap anggota seperti dirinya, menaruh perhatian yang besar dan keinginan yang kuat dalam melaksanakn tugas-tugasnya. Pemimpin beranggapan bahwa bila setiap anggota melaksanakan tugasnya secara efektif dan efisien, pasti akan dicapai hasil yang diharapkan sebagai penggabungan hasil yang dicapai masing-masing anggota.

Gaya kepemimpinan yang berpola untuk mementingkan pelaksanaan kerjasama, pemimpin berkeyakinan bahwa dengan kerjasama yang intensif, efektif, dan efisien, semua tugas dapat dilaksanakan secara optimal. Pelaksanakan

17 Fandy Tjiptono \& Anastasia Diana (2011) Total Quality Management, Andi, Yogyakarta, hlm. 161 
dan bagaimana tugas dilaksanakan berada diluar perhatian pemimpin, karena yang penting adalah hasilnya bukan prosesnya. Namun jika hasilnya tidak seperti yang diharapkan, tidak ada pilihan lain, selain mengganti pelaksananya tanpa menghiraukan siapa orangnya. Pola dasar ini menggambarkan kecenderungan, jika dalam organisasi tidak ada yang mampu, mencari pengganti dari luar meskipun harus menyewa serta membayar tinggi. Pemimpin hanya membuat beberapa keputusan penting pada tingkat tertinggi dengan pemahaman yang konseptual. Pemimpin yang efektif dalam organisasi menggunakan desentralisasi dalam membuat keputusannya.

Macam-macam gaya kepemimpinan menurut Dr. Suko Susilo, M.Si. yaitu:

\section{Laissez Faire}

Gaya kepemimpinan laisses faire (bebas lepas) ini memberikan penjelasan bahwa adanya derajat atau intensitas perilaku kepemimpinan yang sangat rendah untuk dua kecenderungan sekaligus. ${ }^{18} \quad$ Pemimpin rendah perhatiannya kepada usaha pembinaan kekompakan kelompok sekaligus memiliki perhatian yang sangat rendah pada penyelesaian tugas-tugas kelompok.

Gaya kepemimpinan ini
memberikan kebebasan mutlak kepada para pengikut. Setiap keputusan diserahkan sepenuhnya kepada pengikut. Pemimpin bersifat pasif dan tidak memberikan contoh kepemimpinan. Pemimpin jenis ini hanya terlibat delam kuantitas yang kecil di mana para bawahannya yang secara aktif menentukan tujuan dan penyelesaian masalah yang dihadapi. Gaya ini sama sekali tidak memberikan perhatian baik pada tugas maupun pada hubungan kerja. Dalam situasi tertentu gaya ini tidak begitu terpuji, karena manajer seperti ini menunjukkan pasif tidak mau ikut campur tangan secara aktif dan pasif. ${ }^{19}$ hlm. 168

18 Suko Susilo, Dasar-dasar Psikologi Sosial,

19 Miftah Thoha (2011), Perilaku Organisasi Konsep Dasar Dan Aplikasinya, PT Raja Grafindo persada, Jakarta, hlm. 312-314

\section{Otoriter}

Gaya pemimpin yang memusatkan segala keputusan dan kebijakan yang diambil dari dirinya sendiri secara penuh. Segala pembagian tugas dan tanggung jawab dipegang oleh si pemimpin yang otoriter tersebut, sedangkan para bawahan hanya melaksanakan tugas yang telah diberikan.Pemimpin merupakan pihak yang berkuasa, sedangkan orang lain adalah pihak yang hanya memiliki tugas, kewajiban dan tanggung jawab. Dalam gaya kepemimpinan otoriter, pemimpin adalah segala-galanya. Pengikut dipandang sebagai pihak yang hanya melaksanakan perintah, sehingga pengikut hanya menerima instruksi, dan tidak diperkenankan membantah atau mengeluarkan pendapat. ${ }^{20}$

Kelebihan model kepemimpinan otoriter ini ada di pencapaian prestasinya. Tidak ada satupun tembok yang mampu menghalangi langkah pemimpin ini. Ketika dia memutuskan suatu tujuan, itu adalah harga mati, tidak ada alasan, yang ada adalah hasil. Langkah - langkahnya penuh perhitungan dan sistematis.

Dingin dan sedikit kejam adalah kelemahan pemimpin dengan kepribadian merah ini. Mereka sangat mementingkan tujuan sehingga tidak pernah peduli dengan cara. Makan atau dimakan adalah prinsip hidupnya.Pemimpin ini paham betul dengan apa yang diinginkanya dan giat mengejarnya. Gaya kepemimpinan ini memiliki ciri-ciri, antara lain menjadikan organisasi menjadi milik pribadi, menetapkan tujuan pribadi dengan tujuan organisasi, memandang bawahan sebagai alat yang tidak berdaya, tidak mau menerima kritik, saran dan pendapat, bergantung kepada kekuasaan formal yang dimilikinya dan memimpin dengan cara paksa. $^{21}$

\section{Demokratis}

Gaya kepemimpinan demokratis adalah gaya pemimpin yang memberikan

20 Arini Tathagati (2016), Orang Kreatif Memimpin Dunia, Progressio Jakarta, Hlm. 37

21Jamal Ma'mur Asmani (2012), Tips Menjadi Kepala Sekolah Profesional, Diva Press, Jogjakarta, hlm. 75 
wewenang secara luas kepada para bawahan. Setiap ada permasalahan selalu mengikutsertakan bawahan sebagai suatu tim yang utuh. Dalam gaya kepemimpinan demokratis pemimpin memberikan banyak informasi tentang tugas serta tanggung jawab para bawahannya. Kepemimpinan demokratis memiliki kecenderungan perilaku yang sangat memperhatikan hubungan-hubungan personal yang dapat membimbing kekompakan dengan dibarengi perhatian yang tinggi terhadap produktivitas kelompok. Dalam kepemimpinan demokratis, pemimpin memandang pengikut sebagai bagian dari organisasi, sehingga pemimpin memberikan tanggung jawab dan wewenang kepada semua pihak. Pengikut diberi kesempatan untuk menyampaikan masukan dan kritik dalam proses mencapai tujuan. Pemimpin bertanggungjawab untuk mengarahkan, mengontrol, mengevaluasi, dan mengkoordinasikan segala sesuatu dalam klompok. ${ }^{22}$

4. Kekeluargaan

Fokus perilaku kepemimpinan ini adalah bahwa anggota kelompok yang dipimpin, dengan segenap harapan dan kebutuhannya sangat diperhatikan serta pemimpin mau dengan senang hati mendengar suara bawahan. ${ }^{23}$

Konsep seorang pemimpin pendidikan tentang kepemimpinan dan kekuasan yang memproyeksikan diri dalam bentuk sikap, tingkah laku dan sifat. Kegiatan kepemimpinan yang dikembangkan dalam lembaga pendidikan atau unit administrasi pendidikan yang dipimpinnya akan mempengaruhi situasi kerja, mempengaruhi kerja anggota staf, sifat, hubungan-hubungan kemanusian diantara sesama, dan akan mempengaruhi kualitas hasil kerja yang mungkin dapat dicapai oleh lembaga atau unit administrasi pendidikan tersebut.

Adapun Gaya kepemimpinan, pada dasarnya mengandung pengertian sebagai suatu perwujudan tingkah laku dari

22 Arini Tathagati (2016), Orang Kreatif Memimpin Dunia, Progressio Jakarta, Hlm. 37

23 Suko Susilo (2013), Dasar-dasar Psikologi Sosial, hlm. 175 seorang pemimpin, yang menyangkut kemampuannya dalam memimpin. Perwujudan tersebut biasanya membentuk suatu pola atau bentuk tertentu. Pengertian gaya kepemimpinan yang demikian ini sesuai dengan pendapat yang disampaikan oleh Davis dan Newstrom. Keduanya menyatakan bahwa pola tindakan pemimpin secara keseluruhan seperti yang dipersepsikan atau diacu oleh bawahan tersebut dikenal sebagai gaya kepemimpinan. ${ }^{24}$

\section{Tinjauan Pondok Pesantren}

Pondok pesantren adalah "sebuah lembaga pendidikan dan pengembangan agama Islam di Indonesia. Pondok pesantren yang pertama adalah pondok pesantren yang didirikan oleh Syekh Maulana Malik Ibrahim atau Syekh Maghribi". ${ }^{25}$

Syekh Maulana Malik Ibrahim dikenal juga dengan nama Sunan Gresik, beliau orang pertama dari sembilan wali yang terkenal dalam penyebaran agama Islam di Pulau Jawa. Tokoh yang dianggap berhasil mendirikan dan mengembangkan pondok pesantren dalam arti yang sesungguhnya adalah Raden Rahmat (Sunan Ampel). "Ia mendirikan pesantren Kembang Kuning, yang pada waktu didirikan hanya memiliki tiga santri, yaitu Wiryo Suroso, Abu Hurairoh dan Kyai Kembang Kuning. Kemudian ia pindah ke Ampel Denta, Surabaya, dan mendirikan pondok pesantren di sana". ${ }^{26}$

\section{Sejarah Perkembangan Pondok Pesantren}

Pondok pesantren memang dari semula adalah sebuah lembaga pendidikan yang khusus untuk mempelajari agama Islam, selain dari itu, pondok pesantren juga menjadi sarana dakwah para penyebar agama Islam ketika masa awal

24 Keith Davis, and John W. Newstrom. (2010), Organizational Behaviour. New York Mc. Graw-Hill Inc, Human Behaviour at Work, halm. 267

25 Salman Risa, 'Pengertian Pondok Pesantren"

26 Tim, 'Perkembangan Pondok Pesantren', dalam, http://www.nabilhusein.com

/index.php?option=com_content\&view=article\&id=59 \&itemid=37, diunduh pada Senin 28 Maret 2017. 
kedatangan Islam di Indonesia. Seiring perkembangan zaman, model pondok pesantren juga turut berubah, beberapa jenis pondok pesantren yang ada hingga sekarang juga bermacam-macam.

Pondok pesantaren pertama kali didirikan oleh Maulana Malik Ibrahim pada abad XV. "Pada saat ini pesantren memperoleh fungsi penting yaitu sebagai pusat penyiaran dan pendidikan agama Islam ".27 "Waktu itu Maulana Malik Ibarahim mendidik sejuimlah santri yang ditampung dirumahnya di Gresik. Santrisantri yang sudah selesai pendidikannya, lalu pulang ke daerahnya masing-masing dan mulailah menyebarkan agama Islam . Kemudian santri-santri tersebut menjadi kyai baru dan mendirikan pondok pesantren". ${ }^{28}$

Pada perkembangan berikutnya proses terjadinya pondok pesantren sangat sederhana yaitu "seorang yang menguasai ilmu tertentu seperti fiqh, tafsir, hadist, dan ilmu ilmu alat bahasa, mereka mulai mengajarkan ilmunya di masjid-masjid, di surau-suarau di tengah-tengah masyarakat lingkungannya. Lama- kelamaan terkenallah kyai tersebut dan pengaruhnya makin luas lalu berdatanganlah santrisantri dari berbagai daerah untuk berguru kepada kyai tersebut". ${ }^{14}$

Tumbuhnya suatu pondok pesantren dimulai dengan adanya pengakuan suatu lingkungan masayarakat terhadap kelebihan yang dimiliki oleh seorang kyai berkenaaan dengan keilmuan dan kesalehannya. Karena keilmuan dan kesalehannya biasanya kyai berpengaruh cukup besar di masyarakat sehingga banyak sekali kyai yang dianggap seabgai cikal bakal suatu desa.

Pondok pesantren merupakan salah satu bentuk sistem pendidikan nasional asli yang telah lama hidup dan tumbuh di tengah-tengah masyarakat Indonesia dan tersebar diseluruh pelosok

27 Abu Bakar Atjeh (1957), Sejarah Hidup KH.Wahid Hasyim dan karangan tersiar, Panitia peringatan KH Wahid Hasyim, Jakarta, hlm. 5.

28 M.Syarif (1980), Administrasi Pesantren, Paryu Berkah, Jakarta, hlm. 5.

14 Ibid., hlm. 6. tanah air terutama di pedesaan. Hampir seluruh pondok pesantern di Indonesia khususnya di Jawa berada di pedesaaan seperti pondok pesantren Tebuireng Jombang, pondok pesantren Denanyar Jombang. pondok pesantren Ploso Kediri. Pondok pesantren Gontor Ponorogo. Dan pondok pesantren lainnya. Pada umumnya pondok-pondok pesantren ini yang dikenal bukannya nama dari pondok tersebut namun desa dimana pondok tersebut.

\section{Jenis-jenis pondok pesantren.}

$\mathrm{Di}$ Indonesia terdapat ribuan pondok pesantren, dari jumlahnya yang ribuan itu bukan berarti antara pesantren yng satu dengan pesantren yang lainnya seragam. "Masing-masing pesantren mempunyai khas yang berbeda-beda. Hal ini disebabkan oleh perbedaan figur kyai dan lingkungan sosialnya dalam ruang dan waktu tertentu".29 Perbedaan ini juga terletak pada orientasi pondok pesantren dalam menghadapi persoalan-persoalan yang berkembang dalam masyarakatnya.

Perbedaan jenis pondok pesantren ini bukan berati melihat pesantren dengan kerangka dekotomis yang ketat, namun dilihat sebagai suatu iklim sosio-religius dimana pola hubungan saling berekat satu sama yang lain. Dengan demikian akan dapat dilihat pesantren dalam proporsi yang sebenarnya sesuai dengan peran yang dimainkan dalam pendidikan dan pengembangan agama Islam

Jenis-jenis pondok pesantren dapat dilihat dari sarana-prasarana, ilmu yang diajarkan, jumlah santri dan bidang pengetahuan. Perbedaan jenis ini memberikan implikasi pada corak pengelolaan dan pendidikan pondok pesantren.

a. Pondok pesantren dilihat dari sarana prasarananya

Menurut Syarif, sebagaimana dikutip kembali oleh Mu'awanah, bahwa tipe pondok pesantren berdasarkan sarana dan prasarana bisa diklasifikasikan sebagai berikut:

29 Hidayat (1985), Pesantren dan Elit Desa, LP3ES, Jakarta, hlm. 74. 
b. Pondok pesantren tipe A, yaitu pondok pesantren yang Kyainya tinggal dalam lingkungan pondok, dan kurikulum pondok terserah kepada Kyai. Cara pemberian pelajaran bersifat individual, dan tidak menyelenggarakan madrasah.

c. Pondok pesantren tipe B, yaitu pondok pesantren yang di dalamnya terdapat madrasah untuk belajar dan tempat santri tinggal. Di lingkungan pesantren juga terdapat tempat tinggal Kyai. Pondok ini memiliki kurikulum tertentu. Pengarahan Kyai bersifat aplikasi, dan jadwal pengajaran pokok terletak pada madrasah yang telah didirikan. Kyai memberikan pelajaran secara umum di madrasah.

d. Pondok pesantren tipe C, yaitu pesantren yang semata-mata untuk tempat tinggal santri. Mereka belajar di sekolah-sekolah dan madrasah di luar pesantren, bahkan ada pula yang belajar di perguruan tinggi umum atau agama. Fungsi Kyai sebagai pengawas dan pembina mental. ${ }^{30}$

e. Pondok pesantren dilihat dari ilmu yang diajarkan.

Berdasarkan keilmuwan yang diajarkan, pondok pesantren terbagi menjadi dua, yaitu salafi dan khalafi. Pondok pesantren salaf (tradisional) menurut Zamakhsyari Dhofier, sebagaimana dikutip kembali oleh Mu'awanah, adalah:

Lembaga pesantren yang mempertahankan pengajaran kitabkitab Islam klasik (salaf) sebagai inti pendidikan. Sistem madrasah ditetapkan hanya untuk memudahkan sistem sorogan, yang dipakai dalam lembaga-lembaga pengajian bentuk lama, tanpa mengenalkan pengajaran pengetahuan umum. Sistem pengajaran pesantren salaf memang lebih sering menerapkan model sorogan dan wetonan. Istilah weton berasal dari bahasa Jawa yang berarti waktu. Disebut demikian karena pengajian model ini dilakukan pada waktu-waktu

30 Mu'awanah (2009), Manajemen Pesantren, STAIN Kediri Press, Kediri, hlm. 19. tertentu yang biasanya dilaksanakan setelah mengerjakan shalat fardhu. ${ }^{31}$

Pesantren khalaf adalah "lembaga pesantren yang memasukkan pelajaran umum dalam kurikulum madrasah yang dikembangkan, atau pesantren yang menyelenggarakan tipe sekolah-sekolah umum seperti; MI atau SD, MTs atau SMP, MA atau SMA, SMK dan bahkan PT dalam lingkungannya. Pesantren modern merupakan pendidikan pesantren yang diperbaharui atau dimodernkan pada segisegi tertentu untuk disesuaikan dengan sistem sekolah". 32

Pesantren juga terbagi menjadi empat, terkait spesifikasi keilmuwan yang ada. "Penguasaan gramatikal bahasa arab, tasawuf, qira'ah Al-Qur'an, dan fiqh. Pondok yang terkait penguasaan gramatikal, contohnya adalah Pondok Lirboyo, Termas, Lasem, dan lain sebagainya. Pondok tasawuf adalah pondok Jampes Kediri sebelum masa perang dunia kedua. Pondok qira'ah AlQur'an adalah Krapyak, Tasikmalaya, Ma'unah Sari. Pondok fiqh adalah pesantren Langitan Tuban". 33

\section{Elemen-elemen Pondok Pesantren}

Baik pondok pesantren salaf maupun khalaf atau apapun jenisnya selalu memiliki, pondok, masjid atau musolla, pengajaran kitab-kitab Islam klasik (kitab kuning) santri dan kyai atau yang sering disebut dengan elmen-elmen pondok pesantren. Elmen-elmen ini saling berinteraksi membentuk suatu komunitas yang utuh dalam lingkungan pondok pesantren. Untuk memperjelas elemenelemen ini dapat dikemukakan hal-hal sebagai berikut.

a. Pondok.

Pada dasarnya pondok adalah "sebuah asrama pendidikan Islam tradisional dimana para santri tinggal bersama dan belajar dibawah bimbingan
31 Mu'awanah, Manajemen Pesantren, hlm. 19.

32 Mu'awanah, Manajemen Pesantren, hlm. 19.

33 Qomar, Pesantren, hlm. 18. 
seorang atau lebih guru atau yang lebih dikenal dengan sebutan kyai atau ustadz". ${ }^{34}$

Pondok pesantren yang besar biasanya mempunyai banyak asrama yang terbagi dalam beberapa komplek dan terdiri dari beberapa kamar.

Kamar yang ditempati oleh santri biasanya berupa bagunan sederhana. "Kamar-kamar pondok biasanya didirikan oleh kyai sendiri dan kadang-kadang didirikan oleh penduduk desa yang taat beragama". ${ }^{35}$ Kyai-kyai yang kaya biasanya mendirikan bangunan pondok sendiri. Bangunan yang mereka buat biasanya seperti tempat diamana mereka pernah nyantri atau seperti pesantren yang pernah mereka kunjungi. Selain itu banyak pula bangunan pondok yang didirikan oleh santrinya masing-masing. Sebagaimana di pondok pesanren Lirboyo banyak bangunan kamar pondok yang didirikan oleh santri. Biasanya santri dari suatu daerah tertentu mengelompok dan bergotong royong mendirikan bangunan kamar. Adapun dana biasanya didapatan dari alumni dan dari bantuan para aghniya' yang mereka kenal. Lain halnya dengan pondok guluk-guluk, santri-santri yang baru mendirikan kamarnya masing-masing dengan dibantu oleh santri-santri senior.

Pondok atau asrama bagi santri merupakan ciri khas pondok pesantren dan sekaligus membedakan dengan sistem pendidikan yang dilaksanakan di masjidmasjid yang berkembang di kebanyakan negara negara Islam yang lain. Bahkan asrama ini pula yang membedakan dengan sistem pendidikan surau di daerah minangkabau.

b. Masjid

Antara masjid dengan pendidikan Islam mempunyai hubungan yang sangat erat. Kaum muslimin telah memanfaatkan masjid untuk tempat ibadah dan sekaligus tempat pendidikan yang disitu dipelajari qaidah-qaidah Islam , hukum-hukum agama, sebagai tempat pengadilan, sebagai tempat pertemuan baggi pemimpin-

6.

${ }^{34}$ Arifin, Kepemimpinan Kyai Sudy kasus, hlm.

35 Soeryo Pratondo (1976), Kapita Selekta Pesantren, Parya Berkah, Jakarta, hlm. 8. pemimpin militer, dan bahkan sebagai tempat menerima duta besar asing. Pendeknya masjid sebagai pusat kehidupan kerohanian, sosial dan politik sehingga masjid-masjid itu sebagai rumah tuhan

Masjid biasanya sebagai cikal bakal pengembangan pondok pesantren. "Seorang kyai yang ingin mengembangkan pondok pesantren biasanya pertama-tama mendirikan masjid di dekat rumahnya". ${ }^{36}$ Masjid ini kemidian dijadikan sebagai tempat yang paling tepat untuk mendidik santri-santri terutama dalam praktek dan pengjaran kitab-kitab klasik

c. Pengajaran kitab kuning

Berbicara tentang pondok pesantren, tidak bisa dilepaskan kaitannya dengan kitab kuning atau kitab-kitab klasik karena pada dasarnya pesantren adalah "lembaga kajian dan pengembangan kitab kuning Menurut Bruinnessen, kitab kuning menunjuk pada sebuah nama yang memberi gambaran warna kertas edisi pertama terbitan Timur Tengah yang sampai ke Indonesia. Kota di Timur Tengah yang terkenal menghasilkan kitab kuning adalah beirut Libanon. Semua kitab-kitab kuning terbitan Beirut sangat bagus kualitasnya". 37

Pada zaman dahulu pada umumnya pondok pesantren mengkaji kitab-kitab kuning bermadzhab syafi'i dan jarang sekali pondok yang yang mengkaji di luar mazhab syfi'i. Namun sekarang kondisinya sudah berbeda, meskipun di luar mazhab Syafi'i apabila dianggap cocok maka juga banyak dikaji.

d. Santri

Santri adalah istilah populer di pondok pesantren yang identik dengan peserta didik. Para santri tinggal di dalam pondok disana mereka memasak dan mencuci pakaiannya sendiri, mereka belajar tanpa terikat waktu.

Dhofir dalam tradisi pesantren terdapat dua kelompok santri yaitu pertama santri mukim: santri yang berasal dari daerah yang jauh dan menetap dalam

\footnotetext{
36 Dhofier, Tradisi Pesantren, hlm. 49.

${ }^{37}$ Arifin, Kepemimpinan Kyai Sudy kasus, hlm.
} 
komplek pesantren kedua santri kalong yaitu santri-santri yang berasal dari desadesa disekeliling pesantren yang biasanya tidak menetap dalam pondok. Untuk mengikuti pelajaran di pondok mereka bolak balik dari rumahnya sendiri.

Santri kalong dan santri mukim ini selalu ada baik pondok besar maupun pondok kecil. Dalam tradisi Islam kegiatan mencari ilmu pengetahuan paling jelas tercermin dalam petualangan seorang santri pergi ke pondok. Kepergian santri ke pondok pesantren pada masa lalu biasanya dilakukan dalam suasana haru dan sakral. Sebelum berangkat nyantri ia diselamati terlebih dahulu, berangkatnya pun mencari hari baik biasanya hari Rabu. Ketika berangkat nyantri semua keluarga mengantar bersama-sama disertai dengan tetesan air mata. Ia tidak diizinkan pulang sebelum 40 hari di pondok. Karena 40 hari adalah ukuran yang menentukan, apakah santri tersebut santri itu kerasan di pondok atau tidak. Jika selama 40 hari dia tidak pulang, maka dimungkinkan ia akan kersan sampai ia tamat. Namun jika belum genap 40 hari ia pulang, maka kemungkinan besar ia tidak akan bisa sampai tamat. ${ }^{38}$

Tradisi pelepasan anak untuk nyantri seperti diatas sekarang ini sudah hampir tidak ditemui. Mereka yang hendak nyatri dianggap sebagaimana anak hendak pergi ke sekolah, tiadak ada sesuatu yang istimewa. Hal ini disebabkan karena mudahnya transportasi dan komunikasi sehingga orang tidak memperdulikan halhal yang berbau sakral, namun kesamaannya ada pada semangat untuk menjadi 'alim dalam hal agama.

e. Kyai

Kyai adalah salah satu elmen dari pondok pesantren yang paling esensial. Seringkali kyai adalah "pendiri dari pondok pesantren. Kalau bukan pendiri biasanya generasi penerus dari kyai pendiri pesantren yang diembani amanat untuk melanjutkan apa yang diririntis oleh kyai sebelumnya. Untuk itu sudah sewajarnya bahwa pertumbuhan pesantren sangat tergantung pada kemampuan dan pribadi kyainya". 39

Pengertian kyai yang paling luas dalam masyarakat Indonesia adalah pendiri dan pemimpin sebuah pondok pesantren atau sebagai muslim terpelajar yang membaktikan hidupnya demi Allah serta menyebar luaskan dan memperdalam ajaran-ajaran dan pandangan pandangan Islam melalui kegiatan pendidikan. Sedangkan pengertian paling sempit adalah seorang ulama' pemimpin pesantren.

\section{Metode Penelitian}

$\begin{array}{lrr}\text { Penelitian ini } & \text { menggunakan } \\ \text { pendekatan kualitatif, } & \text { kemudian }\end{array}$ penggalian datanya menggunakan metode obervasi, interview, dan dokumentasi. Sementara analisis datanya menggunakan analisis kualitatif dari Miles dan Hubberman, dengan tiga tahapan, yakni 1) reduksi data (data reduction), 2) penyajian data (data displays dan 3) penarikan kesimpulan/ verifikasi (conclusion drawing/veriffication). Reduksi data berlangsung terus menerus selama penelitian berlangsung bahkan sebelum data benar-benar terkumpul sudah mengantisipasi akan adanya reduksi data sudah tampak sewaktu memutuskan kerangka konseptual, wilayah penelitian, permasalahan penelitian, dan penentuan metode pengumpulan data.

Yang terakhir kegiatan analisis pada tahap ketiga adalah menarik kesimpulan dan verifikasi. Sejak pengumpulan data peneliti berusaha mencari makna atau arti dari simbolsimbol, mencatat, keteraturan pola, penjelasan-penjelasan, dan alur sebab akibat yang terjadi. Dari kegiatan ini dibuat simpulan-simpulan yang sifatnya masih terbuka, umum, kemudian menuju ke yang spesifik/rinci. Kesimpulan final diharapkan dapat diperoleh setelah pengumpulan data selesai. Adapun tempat penelitian ini bertempat di MTs Al Huda Bogo Nganjuk
38 Ziemek (1986), Pesantren Dalam Perubahan Sosial, P3M, Jakarta, hlm. 146.
39 Dhofier, Tradisi Pesantren Studi, hlm. 55. 
intëlëktuãl

Jurnal Pendidikan dan Studi Keislaman
Hasil Penelitian

Setiap pemimpin dalam menjalankan kepemimpinannya mempunyai cara dan gaya masing-masing. Pemimpin itu mempunyai sifat, kebiasaan, temperamen, watak dan kepribadian sendiri yang khas, sehingga tingkah laku dan gayanya yang membedakan dirinya dari orang lain. Ada pemimpin yang keras dan represif, tidak persuasif, sehingga bawahan bekerja disertai rasa ketakutan, ada pula pemimpin yang bergaya lemah lembut dan biasanya disenangi oleh bawahan. Kegagalan atau keberhasilan yang dipimpin dalam melaksanakan tugastugas perkerjaannya menunjukkan kegagalan atau keberhasilan pemimpin itu sendiri.

Orientasi kecenderungan prilaku pimpinan pondok pesantren Bonggah Ploso Nganjuk lebih mengarah kepada kedua teori yaitu perilaku yang berorientasi kepada pelaksanaan tugas dan produktivitas kelompok kelompok melakukan sejumlah kegiatan dan perilaku yang berorientasi kepada pembinaan kekompakan kelompok, hal tersebut bisa dilihat dari prilaku kyai dalam membina, mengarahkan dan memperlakukan para pengurus dan ustad/ustadzahnya, dalam melaksanakan kegiatan. Hal tersebut sesuai dengan teori yang dijelaskan oleh Dr. Suko Susilo, M.Si.

Gaya kepemimpinan di Pondok Pesantren Al Huda Bonggah Ploso Nganjuk lebih ke gaya Demokratis berdasarkan hasil pengamatan dan wawancara dari berbagai pihak, yang hasil wawancara dan observasi peneliti menunjukkan ciri-ciri gaya kepemimpinan demokratis yaitu gaya pemimpin yang memberikan wewenang secara luas kepada para bawahan. Setiap ada permasalahan selalu mengikut sertakan bawahan sebagai suatu tim yang utuh. Dalam gaya kepemimpinan demokratis pemimpin memberikan banyak informasi tentang tugas serta tanggung jawab para bawahannya. Kepemimpinan demokratis memiliki kecenderungan perilaku yang sangat memperhatikan hubungan-hubungan personal yang dapat membimbing kekompakan dengan dibarengi perhatian yang tinggi terhadap produktivitas kelompok. Dalam kepemimpinan demokratis, pemimpin memandang pengikut sebagai bagian dari organisasi, sehingga pemimpin memberikan tanggung jawab dan wewenang kepada semua pihak. Pengikut diberi kesempatan untuk menyampaikan masukan dan kritik dalam proses mencapai tujuan. Pemimpin bertanggungjawab untuk mengarahkan, mengontrol, mengevaluasi, dan mengkoordinasikan segala sesuatu dalam kelompok.

\section{Kesimpulan}

$\begin{array}{ccc}\text { Akhirnya } & \begin{array}{c}\text { penelitian ini dapat } \\ \text { sebagai }\end{array} \\ \text { disimpulkan } & \text { berikut: }\end{array}$ Kecenderungan orientasi prilaku pemimpin di Pondok Pesantren Al Huda Bonggah Ploso Nganjuk yaitu kecenderungan yang tinggi orientasinya pada pembinaan kekompakan kelompok sekaligus pada pencapaian tujuan.

Pimpinan (Kyai) Pondok Pesantren Al-Huda Bonggah Ploso Nganjuk dalam menujukkan prilaku kepemimpinannya lebih menunjukkan sikap pembinaannya kepada guru, menjaga kekompakan, menjaga keharmonisan hal tersebut terlihat dari cara kyai melakukan pertemuan dalam satu minggu sekali rutin tiap hari jum'at dan melakukan pembinaan setiap sebulan sekali.

Gaya kepemimpinan yang diterapkan oleh Pimpinan Pondok Pesantren Al-Huda Bonggah Ploso Nganjuk adalah Demokrasi. Pimpinan (Kyai) Pondok Pesantren Al-Huda Bonggah Ploso Nganjuk orangnya sangat demokratis, beliau menyadari bahwa dirinya sebagai pimpinan merupakan panutan untuk yang dipimpinnya, beliau memiliki sifat sederhana, sabar, dan memberi kesempatan kepada para Ustad/Ustadzah untuk ikut berperan aktif dalam membuat perencanaan, keputusan serta menilai kinerjanya. Dalam rapat Kyai melibatkan dirinya secara langsung dan membuka interaksi dengan tenaga kependidikan. Keputusan yang diambil Kyai dilakukan berdasarkan musyawarah. Kyai selalu memberi kesempatan kepada para tenaga 
pendidik untuk memberikan masukan dan hasil keputusan berada di tangan Kyai sesuai musyawarah.

\section{Daftar Pustaka}

Agustin, Ari Ginanjar. (2001), ESQ Emotional Spriritual Quotient, Arga Wijaya Persda, Jakarta.

Atjeh, Abu Bakar. (1957) Sejarah Hidup KH.Wahid Hasyim dan karangan tersiar, Panitia peringatan KH Wahid Hasyim, Jakarta

Alya, Qonita. (2011), Kamus Bahasa Indonesia untuk Pendidikan Dasar, , Bandung: Indah Jaya Adipratama.

Aminuddin dkk (2010), Pendidikan Agam Islam Untuk Perguruan Tinggi Umum, , Bogor : Ghalia Indonesia.

Anwar, Moch Idochi (2014), Administrasi Pendidikan Dan Manajemen Biaya Bandung Pendidikan, Alfabeta.

Arifin, Imron. (1993), Kepemimpinan Kyai, kasus pondok pesantren Tebuireng, cet. , Malang.: Pertama, Kalimasada Press.

Arifin, Zaenal, (2016). Efektifitas Kepemimpinan Lembaga Pendidikan Islam di Pesantren. Jurnal Pemikiran Keislaman, 27(1), $\quad 40 \sim 64$. https://doi.org/10.33367/tribakti.v27 $\underline{\mathrm{i} 1.258}$

Asmani, Jamal Ma'mur. (2012), Tips Menjadi Kepala Sekolah Profesional, Jogjakarta.Diva Press.

Burhanuddin, 2013. Analisis Administrasi Manajemen dan Kepemimpinan Pendidikan, , Jakarta.: Bumi Aksara. , Jakarta Dhofier, Zamahsyari. (1995), Tradisi Pesantren: Study Tentang Pandana Hidup Kyai, LP3IS.

Dwiyanto, Agus (2010), Reformasi Birokrasi, kepemimpinan dan Pelayanan Publik, Yogyakarta : Gaya Media.
Faisal, Sanapiah. (1990), Penelitian Kualitatif: Dasar-Dasar dan Aplikasi Malang: YA3.

Hadi, Sutrisno. (1989), Metodologi Research, , Yogyakarta : Andi Offser.

Handoko, T. Hani. (1992), Manajemen, Yogyakarta: BPFE-UGM.

Hidayat, (1985), Pesantren dan Elit Desa, Jakarta : LP3ES.

Irawan, Prasetya. (1999), Logika dan Prosedur Penelitian : Pengantar Teori dan Panduan Praktis Penelitian Sosial bagi Mahasiswa dan Peneliti Pemul STAIN.

Kaloh, J. (2010), Kepemimpinan Kepala Daerah, jakarta : Sinar Grafika.

Moleong, Lexy J. (1991), Metodologi Penelitian kualitatif, , Bandung: Remaja rosdakarya.

Muarif Ambary, Hasan. (2001), Menemukan Peradaban: Jejak Arkeologis dan Historis Islam Di Indonesia, Logos Wacana Ilmu.Mu'awanah (2009), Manajemen Pesantren, Kediri : STAIN Kediri Press.

Muhaimin (2010), Arah Baru Pengembangan Pendidikan Islam:Pemberdayaan, Pengembangan Kurikulum Hingga Redefinisi Islamisasi Pengetahuan, Nuansa: Bandung

Muhaimin (2010) Manajemen dan Kepemimpinan Sekolah/Madrasah. , Jakarta : Kencana Prenada Media Group. 